\title{
REPRESENTATIONS OF NATIVE AMERICANS IN ADAMIC'S WRITING ON (NEW) IMMIGRANTS
}

\author{
Ksenija ŠABEC
}

COBISS 1.01

\section{ABSTRACT}

Representations of Native Americans in Adamic's Writing on (New) Immigrants This article presents an overview of the attention Louis Adamic dedicated to Native Americans in various written works and public engagements and compares it with his writing on new immigrants in the light of his understanding of the importance of the preservation of immigrants' identity and issues of integration and nation-building as they relate to American identity. The article also explores the views on intercultural and interethnic relationships in the United States that Adamic drew on in his treatment of Native Americans. Three works in particular will be analyzed: My America (1938), From Many Lands (1940), and A Nation of Nations (1945). The main finding is that Adamic does not deal as extensively with issues related to indigenous Americans as he does with those related to European immigrants. Nevertheless, Adamic does not completely neglect "the Indian story". In some of his works, most extensively in A Nation of Nations, he specifically compares this story to the (problematic) position of African Americans in an American space that was colonized either "by sword or by book". KEY WORDS: Louis Adamic, Native Americans, immigrants, United States, interculturality

\section{IZVLEČEK}

\section{Reprezentacije ameriških staroselcev v kontekstu Adamičevega pisanja}

o (novih) priseljencih

Članek se ukvarja z vprašanjem, kakšno pozornost je Louis Adamič v izbranih delih in javnem angažiranju namenjal ameriškim staroselcem $v$ primerjavi s svojim pisanjem o novih priseljencih v kontekstu razumevanja ohranjanja priseljenske identitete, problema integracije in oblikovanja ameriške nacionalne identitete. Poleg tega raziskuje načine, na katere je avtor obravnaval medkulturne in medetnične odnose v ZDA s stališča ameriških staroselcev. Analizirana so predvsem tri njegova dela: Moja Amerika (1938), Iz mnogih dežel (1940) in Narod narodov (1945). Glavna ugotovitev je, da Adamič ameriškim staroselcem ne posveča enake pozornosti kot (evropskim) priseljencem, kljub temu pa »indijanske zgodbe« ni popolnoma zanemaril. V nekaterih svojih delih, najbolj v Narodu narodov, jih je še zlasti vzporejal s (problematičnim) položajem temnopoltih v Združenih državah v času, ko je bil ta prostor koloniziran ali "z mečem ali s knjigo«.

KLJUČNE BESEDE: Louis Adamič, ameriški staroselci, priseljenci, ZDA, medkulturnost

PhD in Social Sciences, Assistant Professor, University of Ljubljana, Faculty of Social Sciences, Kardeljeva ploščad 5, SI-1000 Ljubljana; ksenija.sabec@fdv.uni-lj.si 


\section{INTRODUCTION}

It seems unbelievable that the name Louis Adamic is, at least in the Slovenian milieu, so rarely mentioned in the contemporary era, when intercultural communication, intercultural dialogue, intercultural skills and intercultural upbringing have become almost the ultimate imperative of contemporary educational systems, if not also of the wider public discourse, a nearly unavoidable tour de force, or what Boris Vezjak termed "the a priori positivism of dialogism" (2008: 79). With the exception of relatively narrow academic circles and the immediate local community where Adamic spent his early years, anniversaries offer virtually the sole opportunity to revive the memory of Slovenia's best-known emigrant writer and "political loner" (Žitnik Serafin 2009: 127), and for researchers and readers to discover the intercultural content in his work and interpret it in the context of contemporary questions about the possibility and necessity of the coexistence of difference.

That being the case, various individual researchers in academic and professional fields have written a great deal about Adamic's life, his death, his (literary) journalism, lecture tours, political and social engagement, and of course his extensive opus as a public intellectual. For the purpose of this article, the contextualization of Adamic's work in the period of cultural pluralism during the American interwar period and his interpretation of this concept from the perspective of American cultural and ethnic diversity on one hand, and his critical understanding of the economic and social realities of American society on the other, will be necessarily limited and condensed in terms of both content and structure. Two principal figures are dominant in Adamic's work and life: the figure of the immigrant to America and the figure of the American worker. My main question is what place within these two main figures, if any, did Adamic give to Native Americans. Put another way, how did the author, in the context of his own perspective on intercultural and interethnic relationships in the US, deal with this exceptionally (in terms of linguistic and cultural elements) heterogeneous community. We know that Adamic through his work and way of life made a significant contribution to the contemporary concept of multiculturalism, and this is closely connected with his recognition and advocacy of the right that each American has to his or her "own" America (Olivieri 2009: 102).

Adamic's understanding and treatment of Native Americans in the context of American ethnic and cultural diversity will be methodologically addressed through a narrative analysis of the author's three books My America (1938), From Many Lands (1940), and A Nation of Nations (1945), and also on Adamic's social and political engagement and its interpretations. Adamic's lecture tours, during which he met people of "from virtually all classes and backgrounds" (Shiffman 2003: 15) in different American states, frequently conducting deep and personal conversations with them, comprised a significant part of his creative opus. During his professional and consulting work for various institutions, radio stations, etc., he also corresponded with many people and gathered information through personal contacts during his 
travels. From this perspective, the use of narrative analysis seems appropriate, since its units of analysis are field texts, such as stories, autobiography, books, journals, field notes, letters, conversations, interviews, and life experience (Smith 2000). Although it has been criticized for not being "theoretical enough", narrative inquiry is a form of qualitative research. Narrative is a powerful tool in the transfer, or sharing, of knowledge, one that is bound to cognitive issues of constructed and perceived memory. Therefore, it is placed in time, to "assume an experience of time" rather than just making reference to historical time (Polkinghorne 1988).

Whereas narrative analysis is particularly useful for studying the influence of social structures on the individual and his or her perception of the other, the study of the selected works will be set within the broader critical perspective of critical discourse analysis (CDA). The latter is understood not as a special method of discourse analysis nor as one direction of research among many others in the study of discourse, but as an analytical research approach that primarily studies the way socialpower abuse and inequality are enacted, reproduced, legitimated, and resisted in text and talk in both the social and political context. ${ }^{1}$ For inequality is inherently linked to the values through which discursive forms are refracted. CDA could therefore be summarized as a tool for exploring the relationship between texts and contexts, since discourse contains both linguistic and non-linguistic elements, among which the author (Blommaert 2005: 3) particularly emphasizes the material and historical conditions in which texts are produced.

\section{ADAMIC'S TRANSITION FROM CULTURAL PLURALISM TO AN UNDERSTANDING OF AMERICAN IDENTITY AND MULTICULTURALISM}

Adamic's writing on issues of immigration and integration can be contextualized in the period of cultural pluralism during the American interwar period. The term cultural pluralism can be understood as the official precursor to the concept of multiculturalism, introduced by American philosopher Horace Meyer Kallen. It was first used in 1915 in the context of seeking equality and harmony between American culture and other ethnic groups. ${ }^{2}$ After World War II, the period of decolonization and intense anti-colonial movements led to a redefinition of the term. The concept of cultural pluralism was transformed into the term multiculturalism (Lukšič Hacin 2011: 133). It is therefore not wrong to argue that the roots of multiculturalism go back further than

1 In CDA, all methods of the cross-discipline of discourse studies, as well as other relevant methods in the humanities and social sciences, may be used (Wodak, Meyer 2008; Titscher et al. 2000; van Dijk 2015: 466).

2 On the one hand, it defends the importance of preserving the cultural characteristics of ethnic groups, such as language, institutions, cultural heritage and religious affiliation, while on the other, it rejects the assimilationist tendencies that would result in the disappearance of these characteristics (Fishman 2004: 157). 
the 1960s, as related ideas can be found at least as early as the beginning of the 20th century, imbedded in the concept of cultural pluralism, while practice shows them to have been present far earlier within certain socio-historic contexts (Lukšič Hacin 2016: 80). As a term initially embedded in a political concept, multiculturalism first emerged in 1963 in Canada. It occurs in the context of multicultural heterogeneity or coexistence of several cultural and ethnic groups, promoting linguistic, cultural and ethnic diversity as a result of mass migration and cultural and ethnic mixing (Lukšič Hacin 1999: 84-86). From a politically marked term, it eventually transforms into one of the most recognizable yet controversial intellectual-political movements of the second half of the 20th century. With the rise of the multicultural movement in Canada, Australia, and with a slight lag in the United States, Britain, Germany and France, multiculturalism extends beyond the political context to central themes of political philosophy and other theoretical fields, becoming a tool for critical evaluation of cultural relations and ethnic groups within a particular territory (Medica 2011: 209-210). ${ }^{3}$

Although Adamic cannot be directly linked to the use of the term multiculturalism, we can place his works and work within the broader context of writing and acting on the idea of multiculturalism. According to Janja Žitnik Sarafin, Adamic was one of the most productive and certainly the best-known Slovenian emigrant writer, who remained attuned to his "pronounced bi-national socio-cultural involvement" (Žitnik Serafin 2009: 116). He wrote twenty full-length books, around five hundred literary and journalistic articles in magazines and brochures, and left behind numerous unpublished manuscripts. He served as advisor to the project and radio program "Americans All, Immigrants All", which was sponsored by the US government in 1937 and 1938 in an effort to strengthen national unity by highlighting the achievements of various ethnic communities in the US in the era when European Fascism posed an increasing threat. From the 1930s on, he worked to preserve ethnic organizations and movements in the US, and to promote them in American economic, political, social, and cultural life.

He was elected to the executive board of the Foreign Language Information Service, and worked in close contact with other immigrant organizations and the immigrant press. He also collaborated in the foundation of the Common Council for American Unity in 1939, one of the the goals of which was to establish historical archives for individual ethnic groups in the US and disseminate information and teach about them, reform the articulation of American history in a way that recognized the

3 Until the 1990s, the liberal model of multiculturalism prevailed, recognizing rights at the institutional level and ensuring a broader recognition of diversity and more equal inclusion of minority communities in the majority society. After the nineties, however, criticisms of an "idealized" liberal multiculturalism begin to emerge, since the latter does not really manage to eliminate social anomalies in the form of discrimination, inequality and exclusion. Critical multiculturalism, consisting of anti-racist, anti-essentialist movements and postcolonial studies, has emerged as an antipode and a more serious criticism of liberal multiculturalism (Mclennan 2001: 389). 
contributions of all ethnic groups to the development of the US, and gather material for the publication of an encyclopedia of American ethnic groups. Adamic also was the chief editor of the gazette of this organization, called Common Ground. His book A Nation of Nations represents "the first attempt to realize the concept of an encyclopedia of American ethnic groups" (Klemenčič 1981: 1066). In reality, this project would not be completed until 1980 with the publication of the Harvard Encyclopedia of American Ethnic Groups, in which Adamic is mentioned in the introduction as the originator of the idea.

In July 1940, when he was still a leading member of the Council, Adamic became an advisor to a government commission related to the US Council for $\mathrm{Na}$ tional Defense. That same year, the commission included the following statement in its proposal:

[...] fourteen million people are divided from others by the color of their skin, and, as a result of this, cannot contribute their talents and skills in collective endeavors to their country. The commission knows full well that any national program that does not succeed in attracting the participation of all citizens regardless of their background, tribe, faith, or color [...] is inadequate. (in Klemenčič 1981: 1068)

Although it does not explicitly mention Native Americans, the statement refers at least on the declarative level to the potential contribution of Native Americans to American society. In his written works, lectures, and conferences, Adamic had similarly advocated for "a new synthesis of the Old and the New America" (Vecoli, Olivieri 2009: 101), mentioning that American identity in the twentieth century emerges "as much from the first slave ships from Jamestown and from Ellis Island where most immigrants arrive as it does from Plymouth Rock where the Founding Fathers landed" (Olivieri 2009: 102). Adamic believed that the concept of American identity must be based on an understanding of pluralistic identity composed of an interweaving of differences that continually evolves and is redefined, sometimes in a conflictual manner.

Those familiar with Adamic's complex body of work in the field of cultural diversity attribute to him an extremely important, if not the most important role, in the establishment of American ethnic studies and methods of equal treatment of immigrant cultures and values. He was consistently critical in his rejection of the a priori central place of Anglocentric American history in the emergence of the US and the national identity of Americans, and advocated for an ongoing process that would achieve the ideal: "A nation and its identity therefore is not something that must be preserved at all costs, but a nation of communities that must constantly continue to discover and articulate itself on its own" (Žitnik Serafin 2009: 122).

Dan Shiffman $(2005: 57,64)$ defines Adamic as a supporter of "a transitory, progressive pluralism, where pluralism needed to be established before it could be surmounted". In accordance with this concept, the US would cease being a fundamentally Anglo-Saxon society when its identity would be based on "ethnic solidarity 
and championing and protection of distinct groups." However, the protection of individual and cultural differences does not by itself inspire participatory democracy, since culture, according to Adamic, eschews fixed features possessed by discrete groups and represents a process of human and national development, rather than merely a set of inherited traditions. "Culture is creativeness; culture is creation. [...] It is an ideal which approaches reality by the intensity with which it glows and burns in the imagination of a consistently increasing number of people" (Adamic in Shiffman 2003: 68). The complexity of Adamic's thoughts can be found in the simultaneous emphasis he gave to Americanization as a process and the equality of new immigrants with the Old Stock Americans, with no implication that new immigrants, who should participate in national politics, commerce, and the arts, are essentially less evolved than "native" ones. Adamic understood neither ethnic identity on one hand nor Americanization on the other as exclusive concepts, as he believed that their meaning is arrived at through dialog. Throughout his life he maintained a critical stance toward both concepts and called for acceptance of "the other" and respect for differences, because being different, he was "apt to have something out of the ordinary to offer us personally and contribute to the evolving culture and civilization" (Adamic in Shiffman 2003: 145). Adamic's efforts, therefore, anticipate a comprehensive understanding and accepting of equality and diversity in the continuum of multiculturalism, of which the primary source is its dialogism.

\section{REPRESENTATIONS OF NATIVE AMERICANS IN SELECTED WORKS OF LOUIS ADAMIC}

Although Adamic's understanding of intercultural and interethnic relations in the US was complex, and above all extraordinarily comprehensive and pluralistic, two figures predominate in his work and his reflections: the figure of the immigrant (especially second- and third-generation immigrants) and, independent of the former, the figure of the worker. He explored both figures in the socio-historical context of the time, and was particularly influenced in his research by the great economic, social, and cultural upheavals in the US, the economic inequality that was exacerbated after 1929, and his relationship with Yugoslav internal affairs and Yugoslavia in the international context (Klemenčič 1981: 1055). As far as the worker was concerned, Adamic's reflections were ahead of his time, for example when he wrote: "Nowadays, [...], we are producing marvelous machines and erecting fine buildings; on the other hand, the masses of people - at least in the industrial sections - are becoming more and more hectic, jittery, unhappy, unhuman. By unhuman I mean unimaginative, individually or personally uncreative [...]" (Adamic 1938: 396). For Adamic, the class conflict was a fundamental part of America as a paradoxical continent, which fascinates with its cruel nature, human diversity, and merciless economic system that lives on the suffering of others. In his book Laughing in the Jungle, Adamic wrote: "an 
astonishing place, America. One cannot love, nor hate it. It is terrible and magnificent and funny, vacillating between the sublime and the ridiculous" (Adamic 1932: 409). And how in his works did Adamic discuss the first settlers in this "terrible, magnificent, and funny" country?

Adamic often juxtaposed immigrants (New Americans) with "native" Americans, but he did not mean Native American Indians in this context, that is the indigenous original dwellers of the North American continent before the arrival of the first settlers from Europe. Rather he meant Old Stock Americans, the descendants of the first Anglo-Saxon immigrants to the New World who came during the sixteenth and seventeenth century (Adamic 1938: 210). For example, in the chapter in My America (1938) entitled "Ellis Island and Plymouth Rock", he writes about the realization that within its population of slightly less than 130 million, one-third of the American population is of "recent, largely non-Anglo-Saxon immigrant stock, the beginning of whose background in this country is Ellis Island" (Adamic 1938: 207), which was the actual and symbolic point of entry for most immigrants to the US, rather than Plymouth Rock where the first Anglo-Saxon settlers landed and established the first American colony in 1620. According to Adamic, "[t]here should be a recognition of the fact that America is not purely an Anglo-Saxon country", and therefore a new conception of America was necessary (Adamic 1938: 218). Adamic explicitly writes that - being himself an immigrant - he doesn't want to set himself against the Old Stock Americans, but rather to strive for an integrated contemporary America that is not a completed and satisfactory finished product, but rather is the raw material from which the future will be derived, something in the process of emerging and ceaselessly changing.

The old Melting Pot or Crucible idea has not been carried out any too well. Human America is poorly integrated, and I am for integration and homogeneity, for the disappearance of the now sharply defined, islandlike groups, and the gradual, organic merging of all the groups into a nation that culturally and spiritually will be a fusion of all the races and nations now in the United States on the general politico-cultural pattern laid out by the earliest immigrants to this continent and their descendants. (Adamic 1938: 207-208)

Adamic emphasized numerous times in his texts the significance of racial and ethnic diversity and the heterogeneity of American society. In the book Laughing in the Jungle (1932), he criticizes individuals and groups which encouraged and spread antiimmigrant views, especially after the introduction of a quota system for immigrants to the US in 1924, despite the fact that the number of immigrants began to fall drastically in subsequent years. ${ }^{4}$

4 In 1929, 39,000 immigrants were deported or left the country "voluntarily". The annual average in the period from 1930 to 1933 was 29,000 . 
Adamic saw an important shift in reflection in America with the publication of literature specific to so-called "new" Americans, and above all in the revision of history textbooks in a way that recognized and included the contributions to the fabric of the country of immigrant groups from Eastern Europe, the Balkans, and elsewhere..$^{5}$ Among them, said Adamic, there were many who died or were injured just "as early American colonists were killed in subduing the wilderness and in the War for Independence" (Adamic 1938: 220), and in this sense he excludes Native Americans on the American continent or in the so-called "wilderness". The failure to consider the Native Americans is also apparent in the chapter "The Workers" from the same book, in which Adamic writes about the so-called "American process", which has for two hundred years been "fumblingly but consistently, working for more and more democracy [...] and for more and more social, economic, and political liberty and equality, and for the gradual abolition of the country's basic incongruity" (Adamic 1938: 419):

What I call the American Process began quite definitely in the second quarter of the eighteenth century. Its first climax, the Revolutionary War, led to the writing of the Declaration of Independence, the Constitution, and the Constitution's postscript the Bill of Rights; to the birth of a new nation and the establishment of political equality and the freedom of assembly, speech, press, and religion. Its second climax was the Civil War, resulting in the abolition of inequalities between Northern and Southern commerce and the establishment of theoretical equality, in certain respects and functions, for the Negro with the white man. Early in the twentieth century, the question of women's political equality with men came up, and was theoretically settled with the Nineteenth Amendment, letting time put it into practical effect.

In My America, Adamic already outlined his idea about an encyclopedia of ethnic groups, which he then fleshed out more fully in his 1945 book A Nation of Nations. The idea came to him in 1935 when the US Congress approved the WPA program, which included a budget of USD 4.8 billion with the purpose of easing the economic crisis by funding numerous projects, from the construction of roads and bridges to literary, theatrical, and artistic projects. Adamic had the notion that the government could direct several million dollars into the preparation and publication of "a great Encyclopedia of the Population of the United States, from the Indians down to the latest immigrant group" (Adamic 1938: 257). This is one of the few times in his books that Adamic explicitly mentions the presence of Native Americans on the American continent. He spoke about the idea of the encyclopedia many times and in many places, for example in 1935, when Adamic responded critically to philanthropist Anton Phelps Stokes's plans for "an encyclopedia of the Negro". "The Negro Millions

5 Intriguingly, in My America (1938: 253) Adamic fleetingly mentioned that Jews fascinated him intellectually and culturally more than any other race or ethnic group in the US, and that he would like to write a study about them. 
are part of the United States, not separate from it, and I feel they belong along with the Indians, Yankees, and Dutch, and the more recent immigrant strains, in a complete racial encyclopedia, which tell all of us - who we are, what we have in us, etc." (Adamic in Shiffman 2003: 93).

Adamic proposed the following organizing principles for the project: (1) that Ellis Island would become as historically significant as Plymouth Rock; (2) that America is as much the result of contemporary immigrant groups as it is of the early Anglo-Saxon settlers; (3) that people of non-Anglo-Saxon heritage comprised two-fifths of the then US population and had given the country the opportunity to create a unique historical civilization and culture; (4) that America would need to begin to deeply understand these facts in order to avoid internal political, social, cultural, and spiritual difficulties; (5) that with the recent conclusion of mass migration into the US, the time had come for deep reflection about the country's human capital, its potential, and the contributions of individual groups to its civilization, and; (6) that the encyclopedia of the US population represents a step toward the latter. Adamic also saw educational potential as a result of the inclusion of many schools, colleges, universities, newspaper and magazine companies, libraries and churches, immigrant associations, clubs and "millions of individual Old Stock Americans, New Americans, and immigrants". Adamic's concept for the encyclopedia was not realized in his lifetime. "No luck," as he wrote, "but eventually, I think, this job will have to be done - somehow" (Adamic 1938: 258-259).

We can say that Adamic thought about the multi-ethnicity and cultural pluralism in the US (and elsewhere) in an extremely broad, inclusive, and pluralistic manner. In his work, he included in the American cultural mosaic individuals of many ethnicities that shared the experience of emigration from their own countries to the US. Perhaps this was the most obvious in his book A Nation of Nations, which, with the exception of the introduction, was structured according to the countries from which immigrants had come to the US. ${ }^{6}$ Adamic did not dedicate a chapter to Native Americans (or "Indians" or "American Indians" as he called them), as he did, for example, to African ${ }^{7}$ Americans, ${ }^{8}$ in the book and in its illustrations. He put forward an interesting thesis that Native Americans were themselves the descendants of immigrants

6 Adamic included in this group Americans from Italy, Spain, Mexico, France, Holland, Sweden, Russia, Germany, Yugoslavia, Norway, Greece, Poland and Ireland, as American blacks.

7 Adamic used the terms "Negro" and "White" for lack of better expressions as he himself admitted, even though these words were by definition imprecise, represented a racial symbol, and therefore were extremely prejudicial (Adamic 1945: 197).

8 According to Adamic, "the Negroes are the only major element in the American population whose ancestors - on the black side - did not come to the New World of their own free will as emigrants getting away from unsatisfactory conditions in the Old World. This fact caused serious uneasiness to some of the founding fathers as they put forth the proposition that 'all men are created free and equal'." Slavery and race, and above all the attitude the white majority has toward "'color' when it happens to be a permanent part of a man's skin," have made African Americans "a more sharply defined group" than any other in the US (Adamic 1945: 196-197). 
from Asia who came from Siberia across the Bering Strait between ten and fifteen thousand years ago. "Thus, going as far back in the story of American immigration as is possible at present, we can say that the first Americans came from a territory now part of Russia" (Adamic 1945: 144). This thesis is not surprising if we understand Adamic as an author who begins with the belief that American history is the history of immigration.

In A Nation of Nations, and in other texts, ${ }^{9}$ Adamic frequently mentions Native Americans, although generally in connection either to the first colonists who settled on the American continent or to later European immigrants, and very often in the context of their relations to the predominant Anglo-Saxon population. In the chapter on African Americans, Adamic emphasizes the significance of the relations of African Americans to the dominant population in the following quote: "No element of the American population, except possibly the Indians, started out in the modern race for self-improvement with greater handicaps than the Negroes; and for decades the country as a whole did next to nothing to help them - one of the worst examples of communal irresponsibility in modern history" (Adamic 1945: 200). In the same chapter, he describes how "the strains became thoroughly mixed and also absorbed much White and Indian blood, so that the average American Negro is markedly unlike the black African". According to Adamic (1945: 196), America had "a colored 'Melting Pot' as well as a white one; the colored one took in White and Indian blood." Despite these statements, when Adamic explicitly writes about discrimination in the US, he views it primarily in connection with those of Spanish descent, Mexicans immigrants, Germans, most extremely in connection with the African American population, ${ }^{10}$ and to a lesser degree with Jews. "The ultimate test of the American civilization probably will come with success or failure to solve the Negro question", Adamic said, since he recognized the problems facing African Americans as "distinct in degree and quality from those facing other groups and how the need to address these problems was a central challenge to the democratic, spiritual integrity of the nation as a whole" (Shiffman 2003: 92).

The melting pot theory, which undoubtedly influenced Adamic's thinking and writing, argues for a common universal culture that makes cultures and ethnicities renounce their distinctive identities, indigenous languages and values. It is therefore based on the idea that the immigrant population must embrace the social and political values of the host society in order for society to function in a harmonious way, resulting in the amalgamation of cultures (Naseem 2011: 11). The theory became a

9 Here we should mention Adamic's 1937 book The House in Antigua: A Restoration. In midDecember 1936, Adamic went to Guatemala with the intention of writing a book. While there, he encountered the descendants of the indiginous Mayans. Because it does not directly deal with the US, I did not include it in the analysis. In the book, Adamic describes the violence inflicted by Spanish conquistadors on the native population.

10 Adamic also believes that the twentieth century brought important progress in the race situation. Although many blacks were still in a radically unequal situation vis-à-vis whites, certain important mental shifts had taken place. 
political symbol of radical and liberal America and the old assimilationist ideal of the American nation, serving to legitimize the ideology of America as a "Promised Land" where racial, religious, or ethnic affiliations were not expected to affect the possibility of social mobility (Hirschman 1983: 398).

In the chapter on Americans from Spain and Mexico and their relationship with the first colonists, or Old Stock Americans, Adamic describes "a large force of angry Indians" that confronted Juan Ponce de León and his army. Ponce de León landed on the southern coast of Florida in 1513, twenty-one years after Columbus, looking for the Fountain of Youth, which, according to native lore, was located in this region. He spent the next several years attempting to conquer and colonize the region and, despite "Indian hostility", the Spanish eventually succeeded in establishing settlements in Florida before the English occupied the peninsula in 1763. In a subsequent chapter (Adamic 1945: 37, 39), Adamic describes the battles between the Spanish and the "Indians", as well as the "hostility" of the latter, who often killed their enemies and enslaved those that survived, ${ }^{11}$ battles that took place not only in Florida but also on the territory of what would later become the states of Georgia, Tennessee, Alabama, and Mississippi. He gives special attention to the missionaries who arrived starting in the sixteenth century with the intention of converting Native Americans and exploiting their labor to build missions, but were often killed and their missions destroyed, particularly during the period of the American Indian Wars in the 1880s in the region of New Mexico. These uprisings were later suppressed, and more and more Spaniards began to settle in the New World and even to marry Indian women, gradually learning methods of irrigation and harvesting and other agricultural techniques from the Native Americans, while the Native Americans learned the Spanish language. By 1720, roughly twenty-two thousand Spaniards, many of whom had some "Indian" heritage, lived in New Mexico, where nature was not particularly hospitable, as "[t]here were draughts and floods, sometimes unfriendly Indians; pestilences often ravaged the population of this or that valley" (Adamic 1945: 41-42, 46).

In Adamic's opinion, the French behaved correctly toward the Native population in comparison to the Spanish colonists in Florida and New Mexico and the British colonists on the east coast of the American continent. The French also exploited them economically, the early French commercial enterprises being among the largest during the period of American colonization of the sixteenth and seventeenth centuries. The French also came into contact with Native Americans during exploration and hunting activities and while trading in furs. As a result, many male French colonists had relationships with Native American women, and there were also a number of political alliances. Native American men often worked as guides and also as fighters in the French's numerous conflicts with the British and with other Native populations (Adamic 1945: 76). Adamic mentions Anthony Benezet in Michel Guillaume Jean de Crèvecoeur as two of the most important names among French settlers before the

11 The example used was Pánfil de Narváez's 1528 expedition in Florida (Adamic 1945: 39-40). 
American Revolution. Benezet in particular took a great interest in Native Americans when he lived in Philadelphia before his death in 1784 (Adamic 1945: 81-82). In the chapter about Americans from Holland, Adamic does not neglect mentioning the Walloon Peter Minuit, who, under the auspices of the Dutch West India Company, became the Director of New Netherland during the period from 1626 to 1631, and was best known for supposedly negotiating the purchase of the island of Manhattan from the Lenape tribe in exchange for jewelry worth approximately twenty-four dollars (Adamic 1945: 96). Manhattan subsequently became part of Dutch New Amsterdam and later New York City.

Adamic also mentions Native Americans in the chapter about Swedish colonization, because, in Adamic's opinion, the relations of Swedish colonists to the indigenous people stands out from all the other immigrant groups. Swedes and also Finns treated the Native Americans fairly and honestly and to a great agree accepted them as being "the rightful masters of the country". In contrast to the British, Dutch, and Spanish, "the Swedes did not fight the Indians; on the contrary, they enjoyed their good will and cooperation" (Adamic 1945: 123). Although William Penn, who came from England in 1682 to establish a Quaker colony in Pennsylvania, was justifiably known for his humane policies toward the Native Americans, much of the credit should go the Swedes who for the preceding two generations had cultivated honest relations with the Native Americans in the wider region.

In his book Swedes in America (1938), Amandus Johnson wrote: "The Indians would not have had confidence in the white man, had they been treated by the Swedes as they were treated by the English and the Dutch. William Penn's interpreters were Swedes, and the Indians relied on their word when they assured them that William Penn was honest and would treat them justly" (Adamic 1945: 124). The Swedish official policy toward the indigenous Americans, which the Swedish King Gustavus Adolfus (1594-1632) had defined when the American colony of New Sweden was only an idea, included the Christianization of the Native Americans. For this reason, one of the most important figures in the Swedish colonies was the Lutheran minister Johan Campanius, who arrived in Delaware in 1643 and became one of the first Christian missionaries to live among the Native Americans. Campanius was an intellectual and a scholar who studied the traditional ways of the Native tribes, learning their languages, and thus earning their affection and respect. It is due to him that certain Native Americans called the Swedes Netappi, which translated as "our people", the complete opposite of how they viewed the British and Dutch (Adamic 1945: 125).

Adamic writes about Christian Priber as someone who also treated the Native American population with equality and fairness. Priber was a German scholar from Saxony who, having lived in Britain for some time, went to South Carolina in the 1730s. He came to America with the idea of establishing "a perfect state called Paradise" where he would be the premier (Adamic 1945: 173). He traveled unarmed on horseback across five hundred miles of "wild Indian country" beyond the Smoky 
Mountains. His ideas about a perfect republic and the conviction that it was close to realization must have been very persuasive to the Native American leaders. Forty years before the American Revolution, Priber preached that all people were born equal and free, that women were equal to men, and that tyranny and all of the evil associated with it should be driven from "this virgin continent" before it was too late. Because Priber was actually very close to organizing southern Native tribes and many white settlers into a powerful movement, the French and British border patrols chose not to confront him militarily but instead arrested him and incarcerated him in a British fort on St. Simons Island in the state of Georgia, where he lived until his death.

It is also worth noting the connection that Adamic made between Native Americans and Yugoslav immigrants. The Yugoslav chapter in the American story, as Adamic writes in A Nation of Nations, probably began with the first European settlement of America. It is very probable that "cosmopolitan Croatians" sailed on Columbus's ships from the famed citystate of Ragusa (Dubrovnik). During this era, sailors and shipping lines from Ragusa were considered among the best in the world because of their long maritime tradition. In the fifteenth and sixteenth centuries, members of Dalmatian naval guilds sailed for all the maritime nations, especially for those that were active in the Indian spice market, and some of them undoubtedly joined "the great Adventure" of 1492, when ships sailed from Ragusa toward America during the half century after it was discovered.

It is almost certain that a fleet of ships sailed from Dubrovnik to America around the year 1540 and that there was room on these ships for refugees who had fled the interior of the Balkans from Turkish authorities. Some of these ships were wrecked on the shores of North Carolina, probably Roanoke Island. The sailors that survived mixed with the indigenous population there, and their descendants were known as "Croatan Indians or Croatans". As Adamic writes, a group of inhabitants in Robeson County, North Carolina, the descendants of Croatian immigrants to America, still carried the Croatan name even in his day. Similar groups lived in West Virginia and in Cumberland County in Maryland. There is an island by the name of Croatan in Cartaret County in North Carolina, and the Croatan Sound connects the Albemarle and Pamlico Sounds. "Croatoan Indians" were "found" in the mid-1580s when Walter Raleigh sponsored the first colonies in Roanoke, and although certain authors have expressed doubts about the name and heritage, Adamic (1945: 235) finds the theories about "Croatoan Indians" entirely credible.

Another connection that Adamic makes between Native Americans and Yugoslavs in America can be found in the figure of the Slovenian priest Frederic Baraga, who arrived in the wilderness of northern Michigan and Minnesota in the early 1830s, where he worked with the Chippewa and Ojibwa tribes. As the only son in the family, Baraga had left the Carniola region of Slovenia, selling his family property, and had 
been living in America for some time when he began to send leaflets ${ }^{12}$ to parishes around Slovenia in an effort to raise money for his projects. For years, Slovenian farmers contributed to "Baraga's Indians". Baraga learned their language, compiled grammatical rules, translated the Bible, and wrote two religious books in the language of these tribes. In A Nation of Nations, Adamic describes his encounter with a "sad-faced middle-aged" member of the Chippewa people on an Indian reservation in Baraga County, Michigan. When Adamic asked him if he knew anything about Frederic Baraga, who had died in 1868 and had been the first Bishop in the Roman Catholic Diocese of Saulte Sainte Marie in Marquette, he responded:

My father and grandfather often spoke of him. [...] For thirty-five years he walked hundreds of miles every few months through the virgin forests of this region - often alone, sometimes with an Indian companion; sleeping in the woods like an Indian. My grandfather knew him well and used to say that Baraga moved among us as though he saw something before him." (Adamic 1945: 237)

According to the stories of this man's grandfather, Baraga was always good to the "Indians" and really wanted to help them. He respected the "Indians" as human beings, respected their language and their customs, and their difficulties in "the strange new world growing up around them". He fought for their rights, paying visits to the governors of Michigan and Washington in their name. He tried to convert even corrupt "Indian agents" and to raise "Indian" self-confidence so that whites would no longer be able to take advantage of them and would begin to respect them. Baraga realized that the invasion of Europeans would destroy the Native American peoples if they did not establish permanent settlements and begin to engage in more advanced methods of agriculture in addition to hunting and fishing. This is why he spent years teaching them to use the plough and the harrow, to sow and to harvest. He established churches and schools, and helped them build their own when he became bishop. As a first-rate carpenter, he also trained Native Americans in the craft and attracted other Slovenian missionaries to America with his work. Adamic (1945: 238) writes:

Here and there Baraga succeeded for a time; in the long run, however, the odds were too heavy against him and against the Red man. He could not quell the rapacity of the new mining and timber industries which in the next three-quarters of a century turned the beautiful and rich Upper Michigan area into a ghost region. He could not keep out the "fire-water" that the Pale Face used in trading operations with the Indian. Washington was unresponsive; Indian agents were too deeply mired in corruption. [...] His attitude toward the Indian is now recognized as sound. In the 1930s,

12 One of Baraga's leaflets was part of a collection of the Minnesota Historical Society's museum in Saint Paul (Adamic 1945: 237). 
with John Collier as Commissioner of Indian Affairs, the United States government began to put into effect the policy and the practices that Baraga started a hundred years before.

\section{CONCLUSION}

This article is one of the first to address the question of what attention Louis Adamic paid to Native Americans in selected works in the context of American ethnic and cultural diversity, since there are practically no resources on this topic. This is also understandable due to the fact that during my research only a few references to Native Americans were found in Adamic's A Nation of Nations and My America. Even the book From Many Lands (1940), which won the Anisfield Award for the best work about race relations and is structured according to the ethnic affiliations of individuals whose personal stories of their experiences multiethnic and multicultural America Adamic collected during the winter of 1938-39 from questionnaires published in several immigrant and foreign-language newspapers and also from letters, contains no stories about Native Americans. These stories, about German, Croatian, Czech, Finnish, Polish, Greek, Armenian, Slovenian, Dutch, Japanese, and Mexican immigrants, not about Old Stock Americans, the first immigrants to America, confirm the thesis that Adamic's attention was mostly directed toward immigrants that began to settle the American continent after its "discovery" by Europeans, and especially during the period of Adamic's work and creative output in the first half of the twentieth century. Nevertheless, he did not completely neglect the so-called "Indian story". In some of his works, especially A Nation of Nations, Adamic compared the situation of Native Americans with the (problematic and difficult) situation of African Americans while also describing the early and later European immigrants who colonized the American space either "by sword or by book".

In the 1930s, when Adamic had the reputation of an important writer and public intellectual, the prevailing concept in the US was one of cultural relativism. A movement for intercultural education emerged at that time. This was strongly supported by Adamic, along with giving increased importance to "enlightened" intercultural communication. It is not surprising that numerous organizations around the country began to provide American schools and teachers with material about different ethnic heritages and intercultural understanding. Even the use of the term "minority" as a combination of racial and cultural differences was first used in this period, and quite quickly replaced the old concept of race and racial groups, directing attention to the situation of these groups in society (Gleason in Shiffman 2005: 66-67).

Adamic perceived and conceived of America, with its plethora of different ethnicities and cultures including Native Americans, as the embryo of a global "panhumanistic" democracy which would ultimately be capable of abolishing racism and nationalism. Olivieri (2009: 105) described this as Adamic's universalist stance. 
As a "political loner" who was tirelessly socially engaged, Adamic's key role in the emergence of American multiculturalism was his advocacy for concepts relating to immigrant problematics, which, according to Žitnik Serafin (2009: 127-128), "are as relevant and convincing today as they were when he published them."

\section{REFERENCES}

Adamic, Louis (1932). Laughing in the Jungle. New York, London: Harper \& Brothers Publishers.

Adamic, Louis (1938). My America 1928-1938. New York, London: Harper \& Brothers Publishers.

Adamic, Louis (1940). From Many Lands. New York, London: Harper \& Brothers Publishers. Adamic, Louis (1945). A Nation of Nations. New York, London: Harper \& Brothers Publishers.

Blommaert, Jan (2005). Discourse: A Critical Introduction. New York: Cambridge University Press.

Fishman, Donald A. (2004). Mainstreaming Ethnicity: Horace Kallen, the Strategy of Transcendence, and Cultural Pluralism. Southern Communication Journal 69/2, 157-172, https://www.tandfonline.com/doi/abs/10.1080/10417940409373286.

Hirschman, Charles (1983). America's Melting Pot Reconsidered. Annual Review of Sociology 9 (August), 397-423, https://doi.org/10.1146/annurev.so.09.080183.002145.

Klemenčič, Matjaž (1981). Politično delo Louisa Adamiča. Teorija in praksa 18/9, 1054-1068.

Lukšič Hacin, Marina (1999). Multikulturalizem in migracije. Ljubljana: ZRC SAZU, Založba ZRC.

Lukšič Hacin, Marina (2011). Teorije, politike in strategije sobivanja v raznolikosti. Medkulturni odnosi kot aktivno državljanstvo (ur. Marina Lukšič Hacin, Mirjam Milharčič Hladnik, Mitja Sardoč). Ljubljana: ZRC SAZU, Založba ZRC, 127-136, http:// www.medkulturni-odnosi.si/images/stories/publikacije/Medkulturni_odnosi. pdf (18. 9. 2019).

Lukšič Hacin, Marina (2016). Theorizing the Concept of Multiculturalism through Taylor's 'Politics of Recognition'. Dve domovini / Two Homelands 44, 79-91.

Mclennan, George (2001). Can there be a 'Critical' Multiculturalism? Ethnicities 1/3, 389-422, https://doi.org/10.1177/146879680100100306.

Medica, Karmen (2011). Večkulturnost (multikulturnost): Večkulturalizem (multikulturalizem). Monitor ISH 13/1, 209-214, http://www.dlib.si/stream/URN:NBN:SI:doc-0RN00TIP/8496ac97-c8bd-4ce9-9aef-39d37d934670/PDF (19. 9. 2019).

Naseem, Muhammad Ayaz (2011). Conceptual Perspectives on Multiculturalism and Multicultural Education: A Survey of the Field. Canadian Issues (Spring), 9-14, https://search.proquest.com/openview/e0895ea7d338df5bb3838e9b0215d8fe/1?pq-origsite=gscholar\&cbl=43874 (23. 9. 2019). 
Olivieri, Andrea (2009). Etnija in razred v misli Louisa Adamiča. Časopis za kritiko znanosti 37/238, 101-109.

Polkinghorne, Donald (1988). Narrative Knowing and the Human Sciences. Albany: SUNY Press.

Shiffman, Dan (2005). Korenine multikulturalizma: Delo Louisa Adamiča. Ljubljana: Založba ZRC, ZRC SAZU.

Smith, Charles P. (2000). Content Analysis and Narrative Analysis. Handbook of Research Methods in Social and Personality Psychology (eds. Harry T. Reis, Charles M. Judd). New York: Cambridge University Press, 313-338.

van Dijk, Teun A. (2015). Critical Discourse Analysis. Handbook of Discourse Analysis (eds. D. Tannen, H. Hamilton, D. Schiffrin. Chichester: Wiley Blackwell, 466-485, chrome-extension://oemmndcbldboiebfnladdacbdfmadadm/http://www.discourses.org/OldArticles/Critical\%20Discourse\%20Analysis.pdf (20. 9. 2019).

Vezjak, Boris (2008). Medkulturna občutljivost kot kriterij dialoškosti. Šolsko polje 19/3-4, 77-94.

Žitnik, Janja (1992). Louis Adamič in sodobniki: 1948-1951. Ljubljana: SAZU, Razred za filološke in literarne vede.

Žitnik Serafin, Janja (2009). Pisatelj med dvema domovinama: Louis Adamič in vprašanja nacionalne, etnične in kulturne identitete. Dve domovini / Two Homelands 30, 115-132. 


\section{POVZETEK}

\section{REPREZENTACIJE AMERIŠKIH STAROSELCEV V KONTEKSTU ADAMIČEVEGA PISANJA O (NOVIH) PRISELJENCIH Ksenija ŠABEC}

Članek izhaja iz kontekstualizacije Adamičevega dela v obdobju pojava kulturnega pluralizma $v$ ZDA med obema vojnama in pisateljevega razumevanja tega koncepta s stališča ameriške kulturne in etnične raznolikosti na eni in njegovega kritičnega razumevanja ekonomske in socialne realnosti tedanje ameriške družbe na drugi strani. V Adamičevih delih in življenju sta nedvomno dominantna dva glavna lika: lik priseljencev, ki so ameriško celino začeli naseljevati po evropskem »odkritju«, še zlasti v času avtorjevega delovanja in ustvarjanja, torej v prvi polovici 20. stoletja, in lik delavcev. Glavno raziskovalno vprašanje v pričujočem članku pa je, kakšno mesto znotraj omenjenih likov - če sploh - je Louis Adamič namenjal ameriškim staroselcem oziroma na kakšne načine je v svojih pogledih na medkulturne in medetnične odnose v ZDA obravnaval to sicer notranje jezikovno in kulturno izredno heterogeno skupnost. Znano je namreč, da je Adamič s svojim delom in z načinom življenja pomembno prispeval k sodobnemu multikulturalizmu, ki je jedrnato povzeto $v$ njegovem zagovarjanju in tudi uresničevanju pravice, da je vsak Američan nosilec »svoje« Amerike. Adamičevo obravnavanje in razumevanje ameriških staroselcev v kontekstu ameriške etnične in kulturne raznolikosti pretežno temelji na analizi njegovih treh monografij: Moja Amerika (1938), Iz mnogih dežel (1940) in Narod narodov (1945), delno pa tudi na pisateljevem družbenem in političnem angažiranju in njegovih interpretih. Avtorica ugotavlja, da Adamič obravnava ameriške staroselce, t. i. »indijanske Američane«, kot prve priseljence na ameriško celino in jim v svojih izbranih delih ne posveča enake pozornosti kot poznejšim (evropskim) priseljencem. Kljub temu pa »indijanske zgodbe« ni popolnoma zanemaril. 